\title{
SISTEM MONITORING SUHU DAN KELEMBAPAN RUANGAN PASIEN ISOLASI COVID-19 BERBASIS IOT
}

\author{
M Arfan Ravy W P, Yosep Agus Pranoto, Mira Orisa \\ Program Studi Teknik Informatika S1, Fakultas Teknologi Industri \\ Institut Teknologi Nasional Malang, Jalan Raya Karanglo km 2 Malang, Indonesia \\ arfanravy@gmail.com
}

\begin{abstract}
ABSTRAK
Situasi pandemi COVID-19 menjadi pembelajaran bagi Indonesia khususnya di bidang kesehatan. Problematika di bidang kesehatan semakin terlihat jelas di era pandemi COVID-19 ini. Kondisi saat ini tentunya menjadi kekhawatiran bagi seluruh masyarakat terkait dengan upaya pengendalian dan penanggulangan Pandemi COVID-19 ini di Indonesia, termasuk juga di kalangan medis dan tenaga kesehatan lainnya. Suhu tubuh normal berkisar antar $36,5^{\circ} \mathrm{C}-37,5^{\circ} \mathrm{C}$ dan bila melebihi $38,5^{\circ} \mathrm{C}$ maka ada indikasi terinfeksi covid-19 yang kemudian akan diarahkan untuk isolasi baik mandiri atau di tempat yang telah disediakan. Tujuan adanya ruang isolasi adalah untuk mengendalikan penyebaran penyakit menular yang bisa mewabah. Ruang isolasi adalah ruangan khusus, orang-orang yang bisa masuk ke ruangan ini juga sangat terbatas. Mengingat di ruang isolasi tidak bisa sembarangan keluar masuk, untuk itu dikembangkanlah sistem monitoring yang mampu memantau beberapa parameter yang dibutuhkan agar ruangan tersebut memenuhi standar operasional prosedur. Salah satunya adalah pengelolaan tata udara yang harus dijaga yaitu suhu ruangan dan kelembapan ruangan. Udara dalam ruangan dan kontaminan dalam ruangan minimal 6x pertukaran udara perjam dengan suhu ruangan 24 - $26 \mathrm{C}$ dan kelembaban relatif 40 - 60\%. Berdasarkan permasalahan diatas penulis ingin menerapkan Fuzzy logic metode Mamdani pada sistem monitoring suhu dan kelembapan ruangan pasien isolasi Covid-19 berabsis IOT ( Internet of Things ). Hal ini tentunya sangat membantu berbagai pihak mulai perorangan, hingga lembaga kesehatan utamanya rumah sakit umum. Dari pengujian metode Fuzzy Logic tersebut diambil 10 data yang dibandingkan nilainya dengan Matlab, dapat dihasilkan rata-rata error output PWM sebesar $0.1 \%$. Bedasarkan pengujian metode black box yang dilakukan dapat diketahui tampilan sistem sesuai dengan tampilan yang diharapkan, dengan persentase kesesuaian 100\%. Untuk pengujian fungsional dapat diketahui tampilan website dapat berfungsi dengan baik pada browser Opera, Chrome, dan juga Microsoft Edge.
\end{abstract}

\section{Kata Kunci : DHT11, MLX90614, Fuzzy Logic, Mamdani, Suhu, Kelembaban}

\section{PENDAHULUAN}

Pandemi covid-19 menyerang hampir seluruh dunia termasuk Indonesia. Kasus penyebaran virus corona di Indonesia terus menunjukkan adanya peningkatan. Langkah pencegahan penularan virus korona salah satunya adalah pemeriksaan suhu tubuh. Pemeriksaan suhu tubuh banyak ditemui di berbagai tempat antara lain kantor, stasiun, bandara, kafe, mall, sekolah atau kampus juga menerapkan cuci tangan dan pengecekan suhu tubuh. Suhu tubuh normal berkisar antar $36,5^{\circ} \mathrm{C}-37,5^{\circ} \mathrm{C}$ dan bila melebihi $38,5^{\circ} \mathrm{C}$ (Achlison, 2020) maka ada indikasi terinfeksi covid-19 yang kemudian akan diarahkan untuk isolasi baik mandiri atau di tempat yang telah disediakan.

Ruang isolasi merupakan ruangan yang didesain khusus untuk menangani pasien dengan penyakit infeksi agar terpisah dari pasien lain. Tujuan adanya ruang isolasi adalah untuk mengendalikan penyebaran penyakit menular yang bisa mewabah. Ruang isolasi adalah ruangan khusus, orang-orang yang bisa masuk ke ruangan ini juga sangat terbatas.

Mengingat di ruang isolasi tidak bisa sembarangan keluar masuk, untuk itu dikembangkanlah sistem monitoring yang mampu memantau beberapa parameter yang dibutuhkan agar ruangan tersebut memenuhi standar operasional prosedur. Salah satunya adalah pengelolaan tata udara yang harus dijaga yaitu suhu ruangan dan kelembapan ruangan. Kemudian diperlukan juga sirkulasi udara yang baik, dan untuk menjaga agar kelembapan ruangan stabil dibutuhkan kipas exhaust. Udara dalam ruangan dan kontaminan dalam ruangan minimal 6x pertukaran udara perjam dengan suhu ruangan $24-26 \mathrm{C}$ dan kelembaban relatif $40-60 \%$. Agar kelembapan stabil dan kipas exhaust bekerja dengan baik, perlu menggunakan sebuah metode dalam hal ini adalah Fuzzy Logic. (DR. Dr. Eka Ginanjar, 2020)

Untuk menangani masalah diatas tentunya kita membutuhkan sebuah teknologi tertentu agar dapat menyelesaikannya. Banyak perkembangan dari teknologi mikrokontroler yang efektif untuk membantu sesuai kebutuhan atau permasalahan yang ada. Berdasarkan permasalahan diatas penulis ingin menerapkan Fuzzy logic metode Mamdani pada sistem monitoring suhu dan kelembapan ruangan pasien isolasi Covid-19 berabsis IOT ( Internet of Things ). Hal ini tentunya sangat membantu berbagai pihak mulai perorangan, hingga lembaga kesehatan utamanya rumah sakit umum. 
Penerapan ini juga akan membantu Dinas Kesehatan sebagai wadah yang menaungi lembaga kesehatan dalam mengendalikan penyebaran penyakit menular khususnya Covid-19. Dampak positif yang akan dirasakan dalam isolasi pasien dirumah sakit maupun isolasi mandiri secara keselurahan adalah perawatan pasien Covid-19 di rumah sakit maupun rumah pribadi dapat terawat dengan Baik, Cepat, Efektif dan Efisien, sehingga dapat mengendalikan penyebaran Covid-19.

\section{TINJAUAN PUSTAKA}

\subsection{Penelitian Terdahulu}

Muchammad Syufi Zakariya (2018) pada penelitian dengan judul" Rancang Bangun Sistem Monitoring Suhu Kelembaban dan Kualitas Oksigen Menggunakan Web Pada Inkubator Bayi Berbasis Arduino". Tujuan penelitian ini adalah agar bisa mengurangi masalah suhu tidak stabil, Untuk mengetauhi kualitas oksigen, suhu dan kelembaban dalam incubator sehingga memperingatkan menurunya kualitas oksigen yang dapat membahayakan bayi, Menghasilkan sistem komunikasi antara perangkat monitoring dan website monitoring sehingga Menghasilkan sistem monitoring yang dapat di akses kapan saja ,dapat meringankan beban perawat ataupun bidan dan juga membuat bayi aman dari bahaya. Adapun persamaan dari penelitian ini tentu sama-sama membuat sistem monitoring dan yang menjadi perbedaan dengan sistem yang dibuat Muchammad Syufi Zakariya, sistem yang dibuat penulis memonitoring Inkubator bayi.

Rizki Fahmin Kafaf (2019) pada penelitian selanjutnya dengan judul "Rancang Bangun Monitoring Suhu dan Kelembaban Kandang Guna Mempermudah Kinerja Peternak Berbasis Arduino". Tujuan penelitian ini adalah mempermudah peternak untuk mengecek suhu kandang sewaktu waktu bila di perlukan. Peternak juga dimudahkan jika ingin mengubah suhu kapan saja jika keadaan diluar kemampuan pengamatan sistem. Adapun persamaan dari penelitian ini yaitu sama-sama membuat aplikasi monitoring berbasis web. Perbedaan pada penelitian dibuat yang Rizki Fahmin Kafaf adalah, sistem yang dibuat penulis memonitoring kandang ternak.

David Agung Nadya Atmaja (2018) pada penelitian selanjutnya dengan judul "Rancang Bangun Pemantauan Suhu Beserta Kualitas Udara Pada Terminal Arjosari Malang Melalui Website Berbasis Arduino". Tujuan penelitian ini adalah membuat rancang bangun alat sistem monitoring suhu dan kualitas udara di lingkungan Terminal Arjosari guna untuk memantau keadaan suhu dan kualitas udara pada lingkungan tersebut. Adapun persamaan dari penelitian ini tentu sama-sama membuat sistem monitoring dan yang menjadi perbedaan dengan sistem yang dibuat David Agung Nadya Atmaja adalah, sistem yang dibuat penulis memonitoring Terminal Arjosari.
Ichwan Nuansyah Putra (2018) Pada penelitian selanjutnya dengan judul "Rancang Bangun Sistem Monitoring Kolam Renang Berbasis Web Dengan Iot" Tujuan penelitian ini adalah memonitoring kualitas kolam renang menggunakan 3 parameter monitoring yaitu kekeruhan, $\mathrm{pH}$ dan suhu. Untuk parameter kekeruhan menggunakan sensor Turbidity. Untuk parameter $\mathrm{pH}$ menggunakan sensor $\mathrm{pH}$ dan untuk parameter suhu menggunakan sensor suhu DS18B20. Arduino Uno sebagai pengolah data dan dikirim menggunakan Module Wifi ESP8266 Adapun hasil pengujian ialah bekerja dengan baik. Sensor Turbidity mampu mengukur tingkat kekeruhan 0-987 NTU. Sensor $\mathrm{pH}$ mampu mengukur tingkat kadar $\mathrm{pH}$ air 0-14. Sensor suhu mampu mendeteksi nilai suhu dengan range $-55^{\circ} \mathrm{C}-125^{\circ} \mathrm{C}$. Dan pada suhu $10^{\circ} \mathrm{C}-$ $85^{\circ} \mathrm{C}$ memiliki nilai akurasi kurang lebih $0.5^{\circ} \mathrm{C}$. Adapun persamaan dari penelitian ini yaitu samasama membuat aplikasi monitoring berbasis web. Perbedaan pada penelitian dibuat yang Risnandar adalah, sistem yang dibuat penulis memonitoring kolam renang.

Alfan Ahmad Afifuddin (2019) Pada penelitian selanjutnya dengan judul "Penerapan Metode Fuzzy Untuk Monitoring Penggunaan Air Rumah Tangga Berbasis Arduino". Tujuan penelitian ini adalah penulis ingin memberikan solusi dengan sistem monitoring penggunaan air yang bisa di akses kapanpun dan dimanapun. dengan implementasi metode fuzzy untuk sistem otomatis pengisian tandon air, sehingga saat kondisi level air dan penggunaan air pada level tertentu maka akan membuka kran pengisian tandon secara otomatis, dengan memanfaatkan sensor ultrasonik dan sensor debit air dengan kontrol arduino. pengolahan data ini yang akan menentukan terbuka tutupnya kran pengisian tandon, untuk menetukan terbuka atau tertutupnya kran pengisian tandon ada beberapa kondisi atau pembacaan sensor yang dijadikan acuan untuk proses ini. dalam hal ini data dari pembacaan sensor debit air akan dikirim ke website dengan menerapkan prinsip IoT. Adapun persamaan dari penelitian ini tentu sama-sama membuat sistem monitoring dan yang menjadi perbedaan dengan sistem yang dibuat Alfan Ahmad Afifudin adalah, sistem yang dibuat penulis memonitoring penggunaan air rumah tangga.

\subsection{Dasar Teori}

\subsubsection{Logika Fuzzy}

Sundari Retno Andani (2013), Logika fuzzy merupakan salah satu komponen pembentuk soft computing. Logika fuzzy pertama kali diperkenalkan oleh Prof. Lotfi A. Zadeh pada tahun 1965. Dasar logika fuzzy adalah teori himpunan fuzzy. Pada teori himpunan fuzzy, peranan derajat keanggotaan sebagai penentu keberadaan elemen dalam suatu himpunan sangatlah penting. Nilai keanggotaan atau derajat keanggotaan atau membership function menjadi ciri utama dari penalaran dengan logika fuzzy tersebut . 
Metode mamdani tak jarang dikenal menjadi metode Max-Min. metode ini diperkenalkan oleh Ebrahim Mamdani tahun 1975. Untuk mendapatkan hasil, diharapkan memenuhi 4 tahapan:

a. Pembentukan himpunan metode fuzzy Pada metode mamdani, baik variable input maupun variable output dibagi menjadi satu atau lebih .

b. Aplikasi fungsi implikasi (aturan) pada metode mamdani, fungsi implikasi yang digunakan adalah min.

c. Komposisi aturan Ada tiga metode yang digunakan dalam melakukan inferensi system fuzzy, yaitu max, additive dan probabilistic OD (probor).

Penegasan Input berdasarkan proses defuzzy merupakan suatu himpunan fuzzy yg diperoleh berdasarkan komposisi himpunan fuzzy, sedangkan hasil yg didapatkan adalah suatu sapta dalam domain himpunan fuzzy tersebut. apabila diberikan suatu himpunan fuzzy menggunakan range eksklusif, maka wajib bisa diambil suatu nilai crisp eksklusif menjadi hasil. Ada beberapa metode defuzzy yang bisa dipakai dalam komposisi anggaran mamadani, yaitu centroid, bosektor, mean of maximum, largest of maximum \& smallest of maximum.

\subsubsection{Tata Udara Ruang Isolasi Covid-19}

Semua lingkungan perawatan pasien diupayakan seminimal mungkin kandungan partikel debu, kuman dan spora dengan menjaga kelembaban dan pertukaran udara. Pertukaran udara dalam tiap ruangan berbeda tekanan dengan selisih 15 Pascal. Ruang perawatan biasa minimal 6 x pergantian udara per jam, ruang isolasi minimal $12 \mathrm{x}$ dan ruang kamar operasi minimal $20 \mathrm{x}$ per jam. (DR. Dr. Eka Ginanjar, 2020)

Optimalisasi ventilasi dapat dicapai dengan memasang jendela yang dapat dibuka dengan maksimal dan menempatkan jendela pada sisi tembok ruangan yang berhadapan, sehingga terjadi aliran udara silang (crossventilation). Meskipun fasilitas kesehatan mempertimbangkan untuk memasang sistem ventilasi mekanik, ventilasi alamiah perlu diusahakan semaksimal mungkin.

Dengan mempertimbangkan adanya penularan secara airborne maka apabila ruangan atau gedung bangunan tidak memenuhi standar desain dan kualitas udara tidak 46 baik dapat menyebabkan transmisi virus SARS-CoV-2 sehingga perlu penerapan pengendalian teknik terhadap sistem HVAC sebagai berikut :

a) Meningkatkan udara segar yang masuk untuk mengencerkan udara dalam ruangan dan kontaminan dalam ruangan minimal $6 x$ pertukaran udara perjam dengan suhu ruangan 24 - 26 C dan kelembaban relatif 40 - 60\%.

b) Pengelolaan aliran udara melalui desain aliran udara bersifat vertical laminar, menjaga aliran udara antar ruangan dengan memasang air curtain atau air gates, mengarahkan aliran udara satu arah dari suplai menuju exhaust.

\subsubsection{Kelembapan Relatif}

Kelembapan Relatif, dinyatakan dalam persen (\%), adalah perbandingan antara tekanan parsial aktual yang diterima uap air dalam suatu volume udara tertentu dengan tekanan parsial udara yang diterima uap air pada kondisi saturasi pada suhu saat itu. (Baiti Hidayati, 2020)

\subsubsection{Arduino Uno}

Arduino Uno adalah board mikrokontroler yang di dalamnya terdapat mikrokontroler, penggunaan jenis mikrokontroler-nya berbeda - beda tergantung spesifikasinya. Pada Arduino Uno diguanakan mikrokontroler berbasis ATmega 328. Memiliki 14 pin input dari output digital dimana 6 pin input tersebut dapat digunakan sebagai output PWM dan 6 pin input analog, $16 \mathrm{MHz}$ osilator kristal, koneksi USB, jack power, ICSP header, dan tombol reset. (Kafafi, 2019)

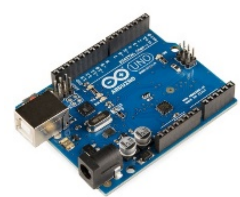

Gambar 1. Arduino Uno

\subsubsection{Node MCU}

NodeMCU adalah sebuah platform IoT yang bersifat open source. Terdiri dari perangkat keras berupa System On Chip (SoC) ESP8266-12 buatan Espressif System, jugafirmware yang digunakan yang menggunakan bahasa pemrograman scripting Lua. Istilah NodeMCU sebenarnya mengacu pada firmware yang digunakan daripada perangkat keras development kit. (Arifaldy Satriadi, 2019)

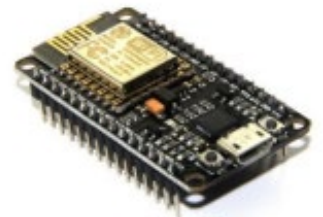

Gambar 2. Node MCU

\subsubsection{DHT11}

DHT11 adalah sensor digital yang dapat mengukur suhu dan kelembaban udara di sekitarnya. Sensor ini sangat mudah digunakan bersama dengan Arduino. Memiliki tingkat stabilitas yang sangat baik serta fitur kalibrasi yang sangat akurat. Koefisien kalibrasi disimpan dalam OTP program memory, sehingga ketika internal sensor mendeteksi sesuatu, maka module ini menyertakan koefisien tersebut dalam kalkulasinya. DHT11 termasuk sensor yang memiliki kualitas terbaik, dinilai dari respon, pembacaan data yang cepat. (Atmaja, 2018) 


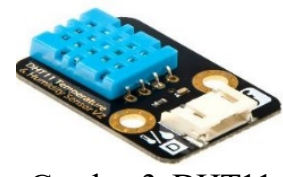

Gambar 3. DHT11

\subsubsection{Sensor Suhu Inframerah MLX90614}

MLX90614 adalah termometer Infra Merah untuk pengukuran suhu non kontak. Berkat penguat noise rendah, ADC 17-bit, dan bertenaga Unit DSP, akurasi dan resolusi tinggi dari termometer tercapai. Termometer telah dikalibrasi oleh pabrik dengan digital Output PWM dan SMBus. Sebagai standar, PWM 10-bit dikonfigurasi ke terus menerus mengirimkan suhu yang diukur dalam kisaran dari 20 hingga $120^{\circ} \mathrm{C}$, dengan resolusi keluaran $0,14^{\circ} \mathrm{C}$. (Dede Irawan Saputra, 2020)

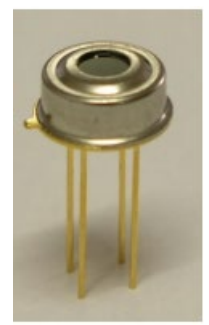

Gambar 4. Suhu Inframerah MLX90614

\section{ANALISIS DAN PERANCANGAN}

\subsection{Analisa Kebutuhan Fungsional}

Adapun beberapa kebutuhan fungsional dalam system monitoring suhu dan kelembapan ruang isolasi Covid-19 :

1. System yang di buat dapat memantau suhu dan kelembapan ruangan yang dibaca melalui sensor DHT11.

2. System yang di buat dapat memantau suhu tubuh pasien yang dibaca melalui sensor MLX90614.

3. System yang di buat dapat menjaga suhu dan kelembapan ruangan menggunakan kipas exhaust.

\subsection{Flowchart Sistem}

Adapun alur proses system dijelaskan pada gambar 4

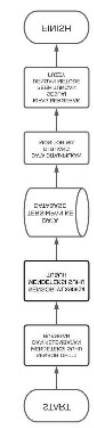

Gambar 4. Alur Proses Sistem Monitoring Ruang Isolasi Covid-19
Pertama sensor DHT11 akan mendeteksi suhu dan kelembapan ruangan, dan sensor Suhu Inframerah MLX90614 mendeteksi suhu tubuh pasien. Data dari sensor dikirimkan ke mikrokontroler dan disimpan di database.

Selanjutnya data suhu ruangan, kelembapan ruangan, dan suhu tubuh muncul ke layar website. Kemudian kipas akan berputar sesuai perhitungan metode.

\subsection{Flowchart Alat}

Adapun alur proses alat dijelaskan pada gambar 5

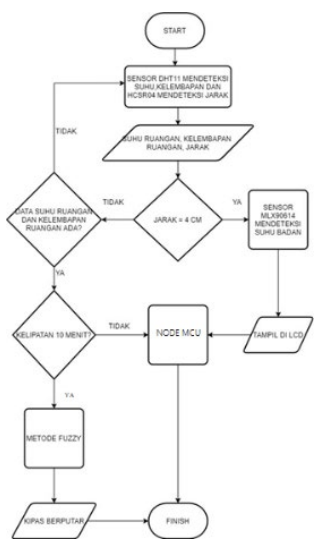

Gambar 5. Alur Proses Alat Monitoring Ruang Isolasi Covid-19

Terdapat empat variabel inputan yaitu suhu ruangan, kelembapan ruangan, jarak, dan suhu tubuh. Suhu ruangan dan kelembapan ruangan dideteksi oleh sensor DHT11 akan dikirimkan ke database secara real time melalui Node MCU. Kemudian sensor HCSR0 4 mendeteksi jarak sama dengan $4 \mathrm{~cm}$, maka sensor MLX90614 akan mendeteksi suhu tubuh dan menampilkannya di LCD. Jika kelipatan waktu 10 menit maka metode fuzzy akan berperan untuk menghitung putaran kipas yang akan dikeluarkan sesuai parameter yang ada yaitu kelembapan ruangan.

\subsection{Penerapan Metode Fuzzy Mamdani}

Penerapan metode Fuzzy Mamdani memerlukan himpunan input, output, dan rule. Dalam sistem monitoring suhu dan kelembapan ruang isolasi Covid-19 ini, terdapat kelembapan ruangan, suhu ruangan sebagai parameter input dan pwm untuk kipas exhaust sebagai outputnya.

1. Himpunan input kelembapan ruangan (rendah, normal, tinggi)

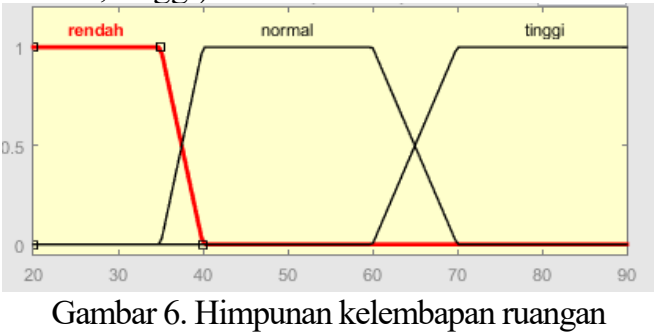


- Himpunan keanggotaan rendah

$$
\mu \operatorname{rendah}(x)=\left\{\begin{array}{cc}
1, & x \leq 35 \\
\frac{40-x}{40-35}, & 35 \leq x \leq 40 \\
0, & x \geq 40
\end{array}\right.
$$

- Himpunan keanggotaan normal

$$
\mu \operatorname{normal}(x)=\left\{\begin{array}{lc}
0, & x \leq 35 \text { atau } x \geq 70 \\
\frac{x-35}{40-35}, & 35 \leq x \leq 40 \\
1, & 40 \leq x \leq 60 \\
\frac{70-x}{70-60}, & 60 \leq x \leq 70
\end{array}\right.
$$

- Himpunan keanggotaan tinggi

$$
\mu \operatorname{tinggi}(x)=\left\{\begin{array}{cc}
0, & x \leq 60 \\
\frac{x-60}{70-60}, & 60 \leq x \leq 70 \\
1, & x \geq 70
\end{array}\right.
$$

2. Himpunan input suhu ruangan (rendah, normal, tinggi)

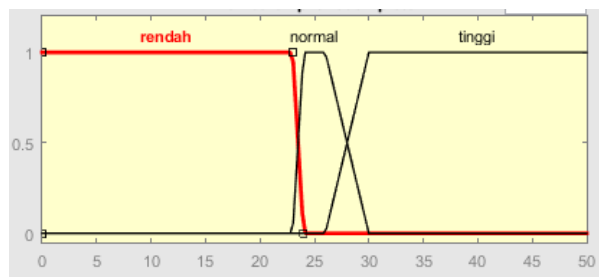

Gambar 7. Himpunan suhu ruangan

- Himpunan keanggotaan rendah

$$
\mu \operatorname{rendah}(x)=\left\{\begin{array}{cc}
1, & x \leq 23 \\
\frac{24-x}{24-23}, & 23 \leq x \leq 24 \\
0, & x \geq 24
\end{array}\right.
$$

- Himpunan keanggotaan normal

$$
\mu \operatorname{normal}(x)=\left\{\begin{array}{cc}
0, & x \leq 23 \text { atau } x \geq 30 \\
\frac{x-23}{24-23}, & 23 \leq x \leq 24 \\
1, & 24 \leq x \leq 26 \\
\frac{30-x}{30-26}, & 26 \leq x \leq 30
\end{array}\right.
$$

- Himpunan keanggotaan tinggi

$$
\mu \operatorname{tinggi}(x)=\left\{\begin{array}{cc}
0, & x \leq 26 \\
\frac{x-26}{30-26}, & 26 \leq x \leq 30 \\
1, & x \geq 30
\end{array}\right.
$$

3. Himpunan Output PWM (lambat, sedang, cepat)

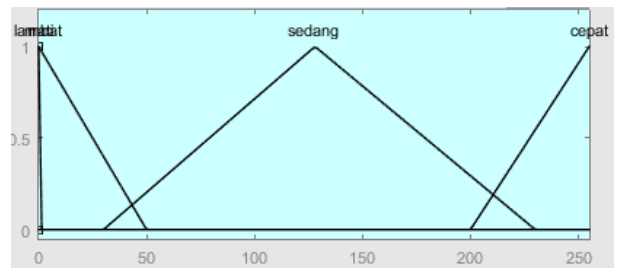

Gambar 8. Himpunan output PWM
- Himpunan keanggotaan mati

$$
\mu \operatorname{mati}(x)= \begin{cases}1, & x=0 \\ 0, & x \neq 0\end{cases}
$$

- Himpunan keanggotaan lambat

$$
\mu \text { lambat }(x)=\left\{\begin{array}{cc}
1, & x \leq 0 \\
\frac{50-x}{50-30}, & 30 \leq x \leq 50 \\
0, & x \geq 50
\end{array}\right.
$$

- Himpunan keanggotaan sedang

$$
\mu \text { sedang }(x)=\left\{\begin{array}{cc}
0, \quad x \leq 30 \text { atau } x \geq 230 \\
\frac{x-30}{128-30}, \quad 30 \leq x \leq 128 \\
\frac{230-x}{230-128}, \quad 128 \leq x \leq 230
\end{array}\right.
$$

- Himpunan keanggotaan cepat

$$
\mu \text { cepat }(x)=\left\{\begin{array}{ccrl}
0, & x & \leq 200 \\
\frac{x-200}{230-200}, & 200 & \leq x \leq 230 \\
1, & x & \geq 255
\end{array}\right.
$$

4. Rule

Tabel 1. Rule (Kelembapan)

\begin{tabular}{|c|c|c|c|}
\hline & Rendah & Normal & Tinggi \\
\hline Rendah & Mati & Lambat & Sedang \\
\hline Normal & Lambat & Sedang & Cepat \\
\hline Tinggi & Sedang & Cepat & Cepat \\
\hline
\end{tabular}

\section{HASIL DAN PEMBAHASAN}

4.1. Rancang Bangun Prototype

Rancang bangun prototipe merupakan rancangan dari sistem yang dibuat yaitu sistem monitoring suhu dan kelembapan ruangan pasien isolasi Covid-19.

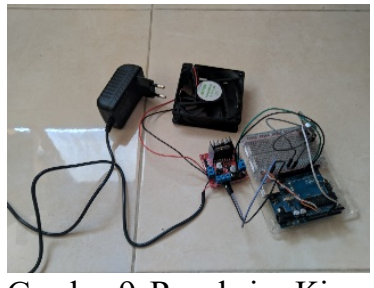

Gambar 9. Rangkaian Kipas

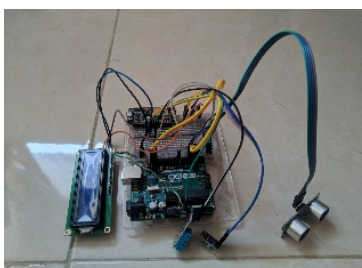

Gambar 10. Rangkaian Sistem Monitoring

\subsection{Tampilan Website}

Halaman dashboard merupakan halaman utama atau halaman home dimana pemilik dapat memantau suhu ruangan, kelembapan ruangan, dan suhu pasien yang ada di dalam ruangan isolasi Covid-19. 


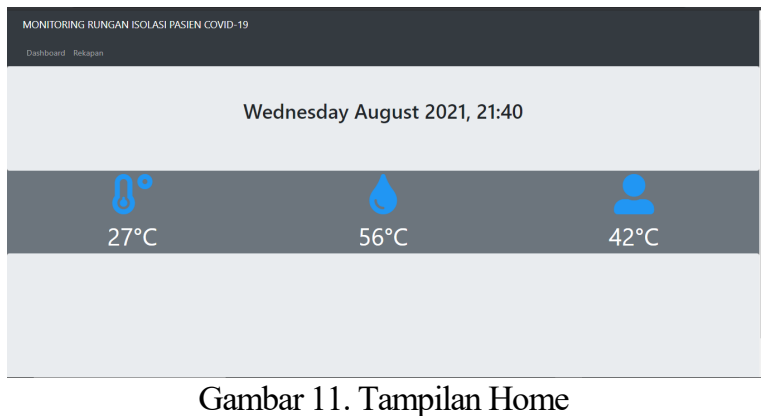

Halaman rekapan website dimana berfungsi untuk menampilkan data suhu ruangan, kelembapan ruangan, dan suhu pasien secara berkala dari waktu ke waktu.

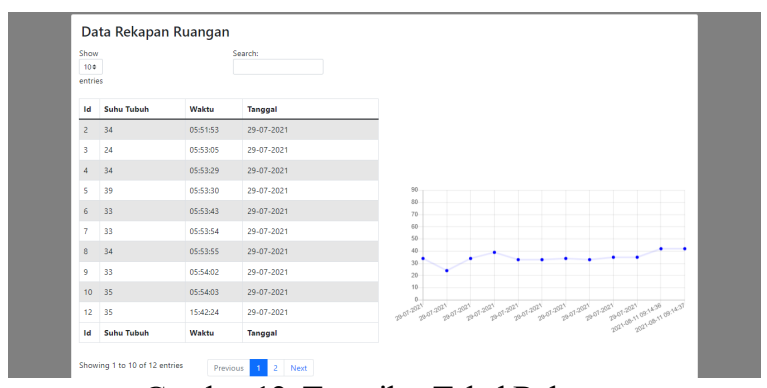

Gambar 12. Tampilan Tabel Rekapan

\subsection{Pengujian Sensor Suhu Tubuh}

Pengujian pembacaan sensor MLX90614 dilakukan dengan cara membandingkan pembacaan sensor dengan alat ukur suhu tubuh Thermogun.

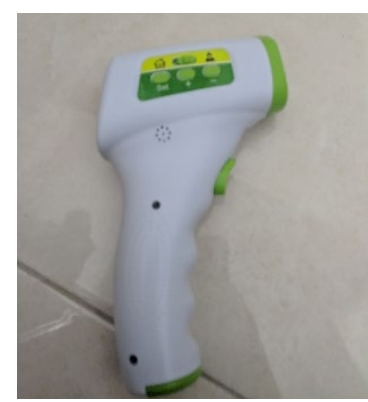

Gambar 13. Thermogun

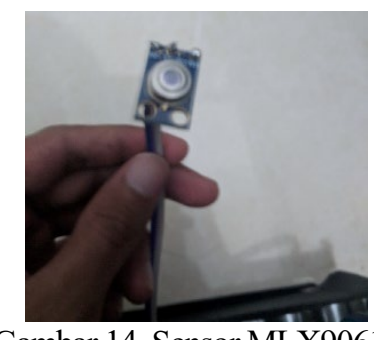

Gambar 14. Sensor MLX90614

Dari hasil percobaan yang telah dilakukan, didapatkan hasil pembacaan seperti pada tabel dibawah ini :
Tabel 2. Pengujian Sensor MLX90614

\begin{tabular}{|l|l|l|l|l|}
\hline No & Sensor & Alat & Selisih & Error \\
\hline 1 & 35.1 & 36.3 & 1.2 & $3.2 \%$ \\
\hline 2 & 35.5 & 36.5 & 1.0 & $2.7 \%$ \\
\hline 3 & 35.0 & 35.9 & 0.9 & $2.5 \%$ \\
\hline 4 & 35.3 & 36.5 & 1.2 & $3.2 \%$ \\
\hline 5 & 35.9 & 37.0 & 1.1 & $2.9 \%$ \\
\hline 6 & 35.2 & 36.3 & 1.1 & $3.0 \%$ \\
\hline 7 & 35.2 & 36.6 & 1.3 & $3.5 \%$ \\
\hline 8 & 35.5 & 36.5 & 1.0 & $2.7 \%$ \\
\hline 9 & 36.0 & 36.9 & 0.9 & $2.4 \%$ \\
\hline 10 & 35.4 & 36.6 & 1.2 & $3.2 \%$ \\
\hline \multicolumn{5}{|c|}{ Rata-rata } \\
\hline \multicolumn{5}{|c|}{} \\
\hline
\end{tabular}

Dari pengujian sensor tersebut diambil 10 data yang dibandingkan nilainya dengan Thermogun, dapat dihasilkan rata-rata error suhu sebesar $2.9 \%$.

\subsection{Pengujian Sensor Suhu dan Kelembapan}

Pengujian pembacaan sensor DHT11 dilakukan dengan cara membandingkan pembacaan sensor dengan alat ukur suhu dan kelembapan.

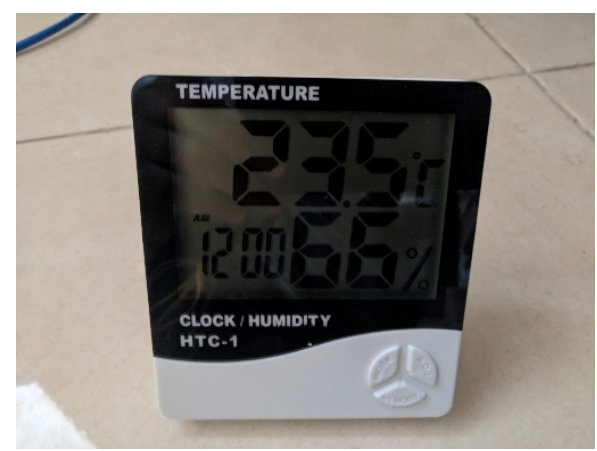

Gambar 15. Alat ukur suhu dan kelembapan

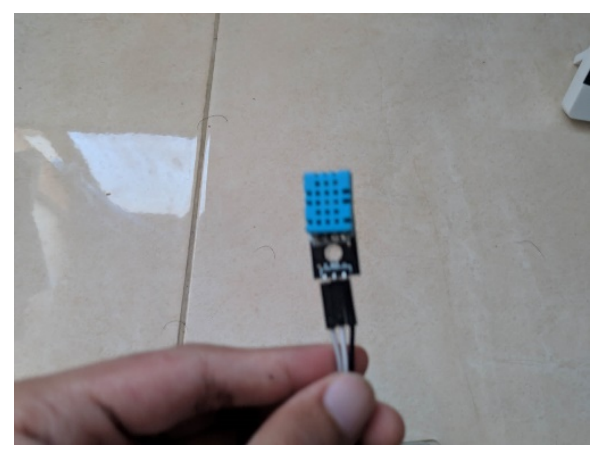

Gambar 16. Sensor DHT11

Dari hasil percobaan yang telah dilakukan, didapatkan hasil pembacaan seperti pada tabel dibawah ini : 
Tabel 3. Pengujian Sensor DHT11

\begin{tabular}{|c|c|c|c|c|c|c|}
\hline \multirow{2}{*}{ No } & \multicolumn{2}{|r|}{ Sensor } & \multicolumn{2}{|r|}{ Alat } & \multicolumn{2}{|r|}{ Error } \\
\hline & Suhu & Kelembapan & Suhu & Kelembaban & Suhu & Kelembapan \\
\hline 1 & 26.0 & 64.0 & 24.3 & 65 & $6.9 \%$ & $1.5 \%$ \\
\hline 2 & 26.0 & 64.0 & 24.3 & 65 & $6.9 \%$ & $1.5 \%$ \\
\hline 3 & 26.0 & 64.0 & 24.3 & 65 & $6.9 \%$ & $1.5 \%$ \\
\hline 4 & 26.0 & 65.0 & 24.3 & 65 & $6.9 \%$ & $0 \%$ \\
\hline 5 & 26.3 & 65.0 & 24.3 & 65 & $8.2 \%$ & $0 \%$ \\
\hline 6 & 26.3 & 65.0 & 24.3 & 65 & $8.2 \%$ & $0 \%$ \\
\hline 7 & 26.3 & 65.0 & 24.3 & 65 & $8.2 \%$ & $0 \%$ \\
\hline 8 & 26.3 & 65.0 & 24.3 & 65 & $8.2 \%$ & $0 \%$ \\
\hline 9 & 26.3 & 65.0 & 24.3 & 65 & $8.2 \%$ & $0 \%$ \\
\hline 10 & 26.3 & 65.0 & 24.3 & 65 & $8.2 \%$ & $0 \%$ \\
\hline \multicolumn{5}{|c|}{ rata } & $7,6 \%$ & $0,4 \%$ \\
\hline
\end{tabular}

Dari pengujian sensor tersebut diambil 10 data yang dibandingkan nilainya dengan alat, dapat dihasilkan rata-rata error suhu sebesar $7,6 \%$ dan kelembapan sebesar $0,4 \%$.

\subsection{Pengujian Metode Fuzzy Logic}

Pengujian metode Fuzzy Logic dilakukan dengan cara membandingkan output PWM dari Arduino dengan output PWM dari simulasi di Matlab.

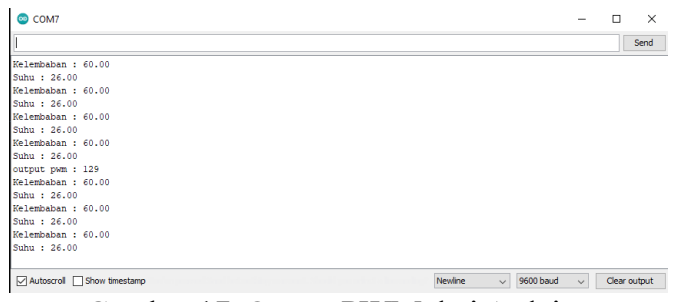

Gambar 17. Output PWM dari Arduino

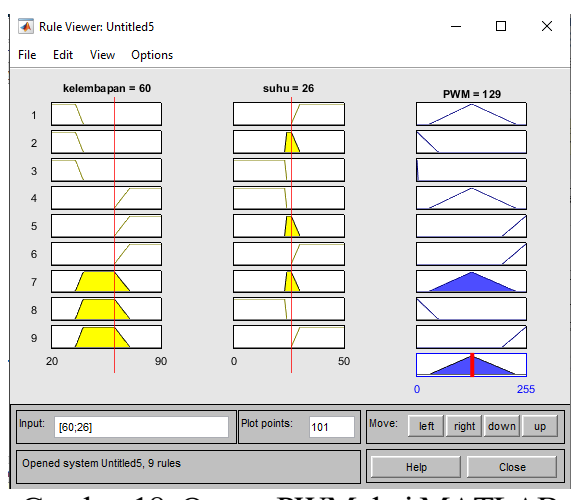

Gambar 18. Output PWM dari MATLAB

Dari hasil percobaan yang telah dilakukan, didapatkan hasil pembacaan seperti pada tabel dibawah ini.
Tabel 4. Pengujian Metode Fuzzy Logic

\begin{tabular}{|l|l|l|l|l|l|l|}
\hline No & Waktu/tanggal & Suhu & Kelembapan & Arduino & Matlab & Error \\
\hline 1 & $11.001-01-21$ & 24.5 & 55.0 & 129 & 129 & $0.0 \%$ \\
\hline 2 & $11.051-01-21$ & 24.5 & 55.0 & 129 & 129 & $0.0 \%$ \\
\hline 3 & $11.101-01-21$ & 24.3 & 55.0 & 129 & 129 & $0.0 \%$ \\
\hline 4 & $12.002-01-21$ & 24.9 & 60.0 & 129 & 129 & $0.0 \%$ \\
\hline 5 & $12.002-01-21$ & 25.0 & 61.0 & 134 & 133 & $0.7 \%$ \\
\hline 6 & $12.002-01-21$ & 25.0 & 61.0 & 134 & 133 & $0.7 \%$ \\
\hline 7 & $11.303-01-21$ & 25.3 & 58.0 & 129 & 129 & $0.0 \%$ \\
\hline 8 & $11.353-01-21$ & 26.0 & 57.0 & 129 & 129 & $0.0 \%$ \\
\hline 9 & $11.453-01-21$ & 25.8 & 57.0 & 129 & 129 & $0.0 \%$ \\
\hline 10 & $11.503-01-21$ & 26.0 & 55.0 & 129 & 129 & $0.0 \%$ \\
\hline \multicolumn{7}{|c|}{ Rata-rata } \\
\hline
\end{tabular}

Dari pengujian metode Fuzzy Logic tersebut diambil 10 data yang dibandingkan nilainya dengan Matlab, dapat dihasilkan rata-rata error output PWM sebesar $0.1 \%$.

\section{KESIMPULAN DAN SARAN}

\subsection{Kesimpulan}

Dari hasil Pengujian dan implementasi yang telah dilakukan, dapat ditarik kesimpulan sebagai berikut :

1. Berdasarkan pengujian sensor MLX90614 yang dilakukan dapat diketahui error rata-rata error pada sensor adalah sebesar $2.9 \%$ dibandingkan dengan alat ukur Thermogen.

2. Berdasarkan pengujian sensor HCSR04 yang dilakukan dapat diketahui error rata-rata error pada sensor adalah sebesar $1.5 \%$ dibandingkan dengan alat ukur penggaris.

3. Berdasarkan pengujian sensor DHT11 yang dilakukan dapat diketahui error rata-rata error pada sensor adalah sebesar 7,6\% untuk suhu ruangan dan 0,4\% untuk kelembapan ruangan.

4. Berdasarkan pengujian metode Fuzzy Logic yang dilakukan dapat diketahui error rata-rata error pada output PWM adalah sebesar $0.1 \%$ dibandingkan dengan output PWM dari Matlab.

5. Bedasarkan pengujian metode black box yang dilakukan dapat diketahui tampilan sistem sesuai dengan tampilan yang diharapkan, dengan persentase kesesuaian $100 \%$.

\subsection{Saran}

Dari hasil penelitian yang dilakukan oleh penulis, maka penulis menyarankan untuk pengembangan penlitian sebagai berikut :

1. Penelitian ini masih bisa untuk dikembangkan dan dilanjutkan dengan menambahkan beberapa parameter, sehingga bisa lebih spesifik lagi dalam memonitoring ruangan isolasi.

2. Membuat website yang lebih baik untuk pengembangan selanjutnya, dan bias menambah platform lain seperti android. 


\section{DAFTAR PUSTAKA}

[1] Achlison, U. (2020). Analisis Implementasi Pengukuran Suhu Tubuh Manusia dalam. JURNAL ILMIAH KOMPUTER GRAFIS, Vol.13, No.2, Desember 2020, 102-106.

[2] Afifuddin, A. A. (2019). Penerapan Metode Fuzzy Untuk Monitoring Penggunaan Air . JATI (Jurnal Mahasiswa Teknik Informatika), 31-38.

[3] Andani, S. R. (2013). Fuzzy Mamdani Dalam Menentukan Tingkat. Seminar Nasional Informatika 20, 57-65.

[4] Andi Adriansyah, O. H. (2013). Rancang Bangun Prototipe Elevator Menggunakan. Jurnal Teknologi Elektro, Universitas Mercu, 100-112.

[5] Arifaldy Satriadi, W. d. (2019). Perancangan Home Automation Berbasis NodeMCU. TRANSIENT, 64-71.

[6] Atmaja, D. A. (2018). Rancang Bangun Pemantauan Suhu Beserta Kualitas Udara Pada . JATI (Jurnal Mahasiswa Teknik Informatika), 380-387.

[7] Baiti Hidayati, B. R. (2020). Analisis Kelembaban Udara Pada Proses Dehumidifikasi. JURNAL AUSTENIT, 1-6.
[8] Dede Irawan Saputra, G. M. (2020). Perancangan Dan Implementasi Rapid JOURNAL OF ENERGY AND ELECTRICAL ENGINEERING, 20-30.

[9] DR. Dr. Eka Ginanjar, S.-K. M. (2020). Pedoman Standar Perlindungan Dokter Di Era Covid-19. Jakarta: PB Ikatan Dokter Indonesia.

[10] Kafafi, R. F. (2019). RANCANG BANGUN MONITORING SUHU DAN . JATI (Jurnal Mahasiswa Teknik Informatika), 98-104.

[11] Nicho Ferdiansyah Kusna, S. R. (2018). Rancang Bangun Pengenalan Modul Sensor Dengan Konfigurasi Otomatis. Jurnal Pengembangan Teknologi Informasi dan Ilmu Komputer, 3200-3209.

[12] Putra, I. N. (2018). Rancang Bangun Sistem Monitoring Kolam Renang . JATI (Jurnal Mahasiswa Teknik Informatika), 116-121.

[13] Suryono, S. (2019). Rancang Bangun Timer Terprogram Dengan Tampilan . ORBITH, 120129.

[14] Zakariya, M. S. (2018). Rancang Bangun Sistem Monitoring Suhu Kelembaban Dan. JATI (Jurnal Mahasiswa Teknik Informatika) , 396403. 